\title{
Understanding of Mosque Managements in Semarang City of Covid-19 Disease and Plague
}

\author{
Nur Fauzan Ahmad ${ }^{1}$, Mudjahirin Tohir ${ }^{2}$, and Muhammad Abdullah ${ }^{2}$ \\ ${ }^{1}$ Indonesian Literature Program, ${ }^{2}$ Master of Literature Program, Diponegoro University, Semarang, \\ Indonesia
}

\begin{abstract}
The Covid-19 pandemic, which has been running for more than two years, has changed the fabric of people's lives, including religious life. This study aims to determine the extent of understanding of the Takmir Mosque Management in Semarang City about illness and the Covid-19 Pandemic Outbreak. The data were taken from documentation and questionnaires distributed to the selected Takmir Masjid management in Semarang Citysin a structured manner with an open-ended question model. The research subjects were determined through purposive sampling, with the criteria of the Takmir Masjid management in Semarang City. The collected data were analyzed by means of descriptive-qualitative. The results showed that the understanding of Takmir mosque administrators in the city of Semarang regarding the Covid outbreak was diverse. The research is expected to provide input for the government in implementing policies for regulating worship in mosques during the Covid-19 pandemic.
\end{abstract}

\section{Introduction}

The biggest problem that is currently being experienced in almost all countries is the Covid19 pandemic problem. The Covid-19 outbreak has been missed has been attacking the world for almost two years, starting with the case in Wuhan, China, at the end of 2019. The emergence of the Covid-19 outbreak caused socio-cultural and religious behaviour in society to change. These changes have an impact on reduced meeting intensity. Indonesian society is known as a friendly society, diligent in meeting face to face. However, since the arrival of the Covid-19 outbreak, the intensity of meetings in various community activities has been very lacking, even almost eliminated. The public is advised not to carry out activities outside the home for an unclear period. Almost all sectors of life are affected by the presence of Covid, from the economic, education, cultural sectors to religious issues. For people ready physically and psychologically, this sudden social change will not have much impact, but for people who are still economically weak and lack understanding of Covid will have a lasting effect. To avoid this impact, a multi-stakeholder approach is needed. One that is no less important is the religious approach.

Data from WHO on May 29, 2021, states that globally there are 223 countries affected by Covid, and 168,599,045 confirmed Covid, of which 3,507,477 people have died. In

* Corresponding author: fazwan.268@gmail.com 
Indonesia, 1,809,926 people have tested positive for the Covid-19 virus, and 50,262 are declared dead [1]. In Central Java, there were 9,148 patients confirmed by Covid-19 and hospitalized or in independent isolation, 180,241 declared cured, and 12,825 people died [2]. Meanwhile, in Semarang City, there were 38,517 people confirmed Covid-19, 96 suspected cases, 327 people treated at the hospital, 27,732 people were declared cured, and 2022 people died [3].

The Covid-19 pandemic has changed the fabric of the world community. To prevent the spread of the widespread coronavirus outbreak, people are urged even to be forced to stay at home. Apart from being detrimental from the health side alone, the Covid-19 virus also impacts the economy in Indonesia, disrupted production of goods, hampered investment. Some goods are becoming expensive and scarce, pilgrims for Hajj and Umrah cancels from leaving for Umrah, Visits of foreign tourists in Indonesia are decreasing, school children are forced to study at home via online, Imports of goods are hampered, mosques and other places of worship are closed, major recitation events are abolished and even going home Eid al-Fitr, and the halal tradition of bi halal are also prohibited.

As time goes by, staying at home is considered unable to be applied forever to maintain economic balance. Several countries have begun to relax policies related to the mobility of their citizens. On the other hand, the SARS-CoV-2 virus that causes Covid-19 continues to threaten. The death toll due to the coronavirus continues to increase. On the other hand, governments in various regions are still imposing Large-Scale Social Restrictions (PSBB) to prevent transmission of the Coronavirus. Public transportation services are not operating normally as before. To restore the economy so that it can return to normal.

Finally, the implementation of a new normal life known as the new normal is carried out. New normal is a behaviour change to continue carrying out normal activities but implementing health protocols to prevent Covid-19 transmission. The main principle of the new normal itself is that it can adapt to life patterns. Socially, we will experience some form of new normal, or we have to adapt to activities and work, and of course have to reduce physical contact with other people and avoid crowds, as well as work, school from home [4].

Fortunately, since the discovery of the Covid vaccine, community activities, including religious activities in mosques, have begun to move again. Almost all mosques have started to open while maintaining strict health protocols. However, there are still many mosques that do not implement this health protocol. Especially the obligation to wear a mask and keep your distance.

This study tries to explore the opinion of the Chairman of the Takmir Masjid in Semarang City about illness, especially Covid-19. The Chairman of Takmir was chosen because they were considered religious leaders who could regulate worship in mosques. The results of this study are expected to help the government in its efforts to suppress and even prevent the spread of the Covid-19 virus with a cultural approach.

\title{
2 Research methods
}

This research uses the purposive sampling method. Sampling was determined based on certain conditions by the research objectives, namely the Takmir Mosque Management in Semarang City. To take a sample from the population, the Slovin formula is used.

$$
n=\frac{N}{1+N e^{2}}
$$

\author{
Information: \\ $\mathrm{n}=$ sample size \\ $\mathrm{N}=$ population size Number of chairman of the Takmir Masjid in Semarang City \\ $\mathrm{e}=$ allowance for inaccuracy because the tolerated sampling error is $11 \%$.
}


Based on data from BPS Semarang City in 2021, the number of mosques in Semarang City is 1,308 . Therefore, $\mathrm{n}=77.8$ is rounded to 78 respondents.

This research is a qualitative study to know the understanding of the Takmir Mosque Management in the city of Semarang towards illness and the covid-19 outbreak. The instrument used was a questionnaire distributed to the Takmir board of the selected mosque in the city of Semarang. The questionnaires were distributed online, given the conditions during the pandemic, and it was deemed very effective. The distribution of questionnaires was carried out from April 2020 to January 2021. The questionnaire results were tabulated and analyzed, which were then combined with interviews, observations, and document studies then outlined in a narrative. Then the results are discussed in a team and then compiled in the form of a scientific report.

\section{Results and Discussion}

\subsection{Meaning of Pain}

Islam is a religion that entirely regulates all aspects of human life to achieve happiness in the afterlife. A healthy condition is needed to achieve this, both physically, psychologically, socially, and spiritually. However, if you are already in a sick condition, Allah SWT also provides a solution to dealing with pain, namely with patience and persistence to get healing, and must be sure that Allah SWT will heal. Because sickness in Islam is a test, the pain reduces sins, and sickness is to attain a higher position. For this reason, the recommendation to maintain health can be made by taking preventive measures (prevention) and curative (treatment). Islam also teaches health care, one example by maintaining cleanliness, as the saying of Rasulullah SAW that: Cleanliness is a part of faith (Narrated by Bukhari).

In the Islamic concept, health and sickness are events and conditions that have always accompanied human life for a long time. Whatever befalls humans are the destiny of Allah SWT; being healthy and sick is a destiny from Allah SWT. The concept of health and illness in Islam is a concept that comes from the views of the Koran and the hadiths. According to the Koran, health and illness are the provisions of Allah. Allah gives pain, Allah also heals (Surah asy-Syu'arâ '26: 78-82). All of that with the aim of testing which is the best in his charity (QS Al Mulk: 2) [5]. Allah creates something or tests His servants; there must be wisdom or lessons behind it all. (QS. Shaad: 27). When a person experiences pain and then acts patiently, resignedly, enthusiastic, and optimistic, Allah will forgive his sins (QS. AlBaqarah: 214). The arguments originating from the Al Quran and Hadith show that the meaning of pain in the Islamic perspective means a test to atone for sins and mistakes. Pain to reach a higher position and illness is proof that Allah SWT wants goodness towards His servants.

The results of research on mahasantri at Al Anwar Sarang Islamic Boarding School stated that among students who have crystallized Islamic religious values, Covid-19, which has so far attacked the world, is considered a trial from God; however, Covid is also considered a creature created by God, and through this event, we are expected to improve the quality of worship to God [6].

In a review of health communication, the meaning of illness is a form of intrapersonal communication related to health. Meanwhile, the meaning of pain in an Islamic perspective shows that pain is interpreted as a test and proof that Allah SWT wants goodness for His creation [7].

Meaning illness for patients with a biased disease has a positive meaning and a negative meaning. A positive purpose occurs when the patient accepts his illness with resignation and patience but keeps trying, has enthusiasm, remains optimistic about recovery, and considers 
his illness a common thing. However, when sufferers have negative meanings and perceptions of illness or illness, the actions and behaviours taken in the treatment or healing process are also negatives [7].

The meaning of tar pain depends on the knowledge and experience of the sufferer. When pain is interpreted as positive or negative, the body responds indirectly. This process involves thoughts and emotions to affect the physical condition of the body (Pasiak, 2012). [8] While the body itself has a set of systems, there is a central nervous system and an immune system, both of which interact, mediated by the HPA (Hypothalamus-Pituitary-Adrenal) axis [7]. In the body, there is two-way communication between the nervous system and immune networks, explaining that behaviour and psychological conditions can affect immunity, and vice versa, the immune process can affect behaviour [9].

The lives of Javanese humans as social beings and individuals are constantly faced with all forms of life problems, so that humans are always required to find various ways to solve every problem in their lives. Understanding the concepts of health and illness will determine how humans respond to the sick system or symptoms that arise in ill individuals [10].

The form of personal knowledge in society regarding the concept and understanding of health and illness is strongly influenced by the environment, ideology, ideas, and values in a community group. Some respond rationally; some are irrational. When rational steps fail, it is not uncommon for them to rely on magic or gahib methods, especially in traditional societies.

\subsection{Understanding of Takmir Mosque Management in Semarang City on Covid-19 Pain and Outbreaks}

In the city of Semarang, there are 1,308 mosques. For this study, 78 respondents came from the Takmir Mosque Management, representing 16 districts in the city of Semarang. Their age is between $20-72$ years old, dominated by $50.5 \%$ aged $50.5 \%$. The last education of the respondents varied from elementary school (2.7\%), high school (13.7\%), D-1 (1.3\%), D-3 (4.1\%), S-1 (45\%), S -2 (27.4\%), S-3 (2.7\%). Of that number, 56\% also received religious education at madrassas, and $63 \%$ had attended Islamic boarding schools. As many as $56 \%$ of the respondents have served as chairman of takmir, the remaining $15 \%$ as secretaries, $20 \%$ as advisors and supervisors, the rest are regular management positions. The length of time he has served as takmir manager ranges from 2 years to the longest, 34 years. When answering the questionnaire, all administrators were in good health, free of Covid-19.

Takmir Masjid is an organization that manages all activities related to mosques, both in building, maintaining and prospering them, including efforts to develop Muslim youth around the mosque [11]. Mosques have a special function as a transcendental medium and a medium for enhancing the social relations of Muslims. Even the mosque is considered as the foundation for the birth of human civilization [12]. The emergence of the Coronavirus Disease (Covid-19) pandemic has resulted in the emergence of various policies issued by the government in response to restrictions on worship to break the chain of the spread of Covid19. On the one hand, it raises an understanding of existing policies; on the other hand, it creates religious conflicts in people's lives [12].

The role of takmir is essential in controlling worship activities in mosques. Whether or not the mosque was closed during the Covid period was primarily determined by the Takmir Management. In response to the Covid-19 pandemic, it turns out that there are various opinions of the Takmir Management in Semarang City, some are obeying the recommendation of the Indonesian Ulema Council (MUI) to delay the implementation of congregational prayers, including Friday prayers, but there are some who are determined to continue to establish congregational prayers at mosques. 
Regarding the problem of health and illness, almost all respondents (95\%) stated that being healthy and sick are entirely the provisions/destiny of Allah SWT; humans can only make efforts while God determines. Some (4.2\%) stated that illness was the result of human actions themselves. This proves the strength of their belief / aqidah of faith. To maintain their health, all coincide with the need for humans to maintain health by maintaining fitness $(93 \%)$, the rest is added to the need to maintain healthy food intake and maintain the heart and the most important thing is to pray to Allah (7\%).

When humans are sick, almost all respondents (84\%) answered that they should seek treatment immediately to recover and rest and pray to Allah. A small proportion (4.2\%) stated that they did not need to seek treatment immediately because they believed illness was an attempt to forgive God. For them, illness is an attempt by Allah to remind them to be aware of their mistakes and how Allah has aborted their sins. Even if you have to seek treatment, all respondents $(98.6 \%)$ refer to paramedics (doctors, nurses, midwives), only a tiny proportion $(1.4 \%)$ refer to Kiyai / Ustadz.

According to them, what they do when they are sick is praying for healing to God after trying to take medicine ( $76 \%$ ); the rest needs to be added by following paramedic advice, resting, eating vitamins and healthy intake and praying.

For them, illness is a test from God for believers to abort sins. They argue that pain is a blessing given to them by God (73\%); some argue that illness is caused by a lack of human health, physical exhaustion, lack of discipline in maintaining personal health and the environment. Besides that, pain is a punishment from Allah to remind people because they forget Him a lot.

Regarding information about Covid-19, most respondents were not too worried. For those dead, alive, sick, including Covid, this has been determined by Allah in lauhil-mahfudz. Humans are only limited to making efforts $(60 \%$. But some of them are quite afraid and panicked in facing this Covid (16\%); others do not believe and need an explanation.

As many as $30 \%$ of respondents believe that this epidemic is a global fabrication deliberately instigated by irresponsible parties who want to rule the world. Some (34\%) think this outbreak is a common epidemic that spreads without human effort; as many as $16.7 \%$ think that corona is a spreading epidemic caused by human negligence. A few argue that viruses are divine creatures; they attack humans because of God's permission. According to most respondents, the corona outbreak is a trial/test from Allah to humans (70\%) and a warning verse and punishment from Allah for human actions far from His rules (29\%). Only a small proportion stated that Covid-19 is an ordinary epidemic unrelated to human behaviour about Allah (1.4\%).

The covid-19 pandemic has reopened theological debates about faith in qadha and qadar. Nowadays, the theme of destiny colours a person's behaviour. Some people sometimes believe in Allah's destiny to refuse to comply with health protocols such as wearing a mask. The causal relationship will die in the face of Allah's destiny. This is often compounded by the opinion that those who strictly adhere to health protocols are considered imperfect in faith and unfairness. The concept of society in such a way usually departs from taking arguments through textually sacred texts without seeing the pre, post, or atmosphere of the text [13].

In responding to the Covid-19 pandemic outbreak, most respondents followed the rules recommended by doctors/government and scholars (MUI), such as staying at home and working at home, wearing masks, constantly washing hands with soap/hand sanitiser (57\%). This means that their level of compliance is relatively high even though there are still some $(42 \%)$ responding to it by continuing to carry out activities outside the home if it is essential, such as praying or shopping for necessities, but by still following the health protocol set by the government.

\section{Conclusion}


The conclusion is 1) Covid-19 has changed the order of life in various areas of human life worldwide, so it is necessary to get used to life with a new normal. 2) The understanding of the Chairman of the Takmir Mosque Management in Semarang that he is sick varies, but almost all think salit is a test and a blessing from Allah, but humans are still required to try to heal with effort. 3) Regarding the Covid-19 outbreak that hit, most of them were not worried; they surrendered and trusted Allah by continuing to try to obey the advice of health experts and the government. 4) According to most respondents, the corona outbreak is a trial/test from Allah to humans, a warning and punishment from Allah for human actions far from His rules. 5) In responding to the Covid-19 pandemic outbreak, most respondents followed the rules recommended by doctors/government and scholars (MUI), such as staying at home and working at home, wearing masks, always washing hands with soap/hand sanitiser, maintaining health. 6) The level of compliance of Takmir Masjid administrators with health protocols is quite high. However, some still respond to it by continuing to carry out activities outside the home if it is essential, such as praying or shopping for necessities but still following the health protocol set by the government.

Suggestions for the government to always work together and involve the leaders of the Takmir Mosque Management to prevent the transmission of Covid -19 in Semarang City. In addition, the government is always expected to improve Covid-19 literacy to the public and provide true and accurate information related to Covid-19 to the Takmir Mosque Management in Semarang City.

\section{References}

1. news.detik.com "Complete Update of RI Corona Case Data May 29, 2021", Retrieved from: https://news.detik.com/berita/d-5586687/update-complete-data-case-corona -ri29-may-2021

2. Distribution of COVID-19 Cases in Central Java (May, 2021) Retrieved from: https://corona.jatengprov.go.id/

3. Information on Coronavirus (COVID-19) Semarang City (May, 2021) Retrieved from: https://siagacorona.semarangkota.go.id/page/covid19

4. Kompas.com, Getting to Know What is New Normal in the Middle of the Corona Pandemic (June, 2020) Retrieved from: https://www.kompas.com/tren/read/2020/05/20/063100865/mengenal-apa-itu-newnormal-di-tengah-pandemi-corona-?page $=$ all

5. Ministry of Religion of the Republic of Indonesia, Al Quran and its Translation, PT Kumudasmoro Grafindo Semarang (1994)

6. F. Febriayanti, Corona Conceptual Metaphors at Mahasantri STAI Al Anwar Sarang, In Proceedings of the Seminar on Linguistics and Literature (Semantics), Language Documentation and Language Policy (2020) Retrieved from: https: //jurnal.uns.ac.id/ semantic proceedings

7. P. Rahmawati, H.Muljohardjono, Meaning of Illness in the Perspective of Health and Islamic Communication, Journal of Islamic Communication, ISBN 2088-6314, 06(02) (December, 2016)

8. T. Pasiak, Spiritual Health Based on Neuroscience, Mizan Bandung (2012).

9. S. Setyawan, The Effect of Aerobic Physical Exercise on the Pattern of the Body's Endurance Response, Dissertation PPS Unair, Surabaya (1995) 
10. H. Wicaksono, Dongke in Tanggulangin Village Community: Understanding the Concept of Health-Sickness and Disease, in Ethnoscience Study of the Medical System Sociology Scientific Journal of Religion, 5(2) (July-December, 2013)

11. Siswanto, Practical Guidelines for Squeezing Organizations, Al-Kautsar East Jakarta (2005)

12. N. Machendrawaty, et.al., Optimization of Mosque Functions in the Middle of the Covid 19 Pandemic (Syar'i Study, Regulation and Application), in Scientific Writing (KTI) Covid-19 Work From Home (WFH) Period UIN Sunan Gunung Djati Bandung (2020)

13. A. Khiddir. Contextualization of the Concept of Destiny and Causality during the Covid-19 Period: A Study on the Analysis of Fahrudin Al Razi in the Mafatihul-Ghaib Interpretation. Thesis at the Faculty of Usuludin and Philosophy, UIN Sunan Ampel Surabaya (2021) 